Part I

Actors, issues and ideologies 


\title{
3 Terrains of neoliberalism \\ Constraints and opportunities for alternative models of service delivery
}

\author{
Ben Fine and David Hall
}

The purpose of this chapter is not so much to demonstrate that neoliberalism is suffering some degree of crisis of legitimacy as it is to explain why, despite this crisis, the momentum behind alternatives to neoliberalism remains so weak. There are good reasons for this, reflecting the extent to which neoliberalism is not merely an ideology and a set of policies to be reversed but is systemically attached to developments across contemporary capitalism over the past 30 years that have been underpinned by, but cannot be reduced to, what has been termed "financialization".

We begin by giving an account of financialization - what it is, what are its effects and what challenges it poses to alternative policy making. Of course, to point to financialization is not to blame finance or the economy for all of the world's woes, even if this is in part an understandable reaction to the current crisis. For neoliberalism is not simply confined to economic imperatives but has also reflected, for example, responses to the collapse of the Soviet bloc, the erosion of the vitality and strength of trade unions and liberation struggles, and the perceived failings of the (welfare) state following the collapse of the post-war boom.

Financialization has, then, involved the excessive expansion and proliferation of financial markets and their penetration into, and influence over, almost every area of economic and social life. But this has occurred against a broader and deeper background of changes that have been systemically disadvantageous to public sector provision. The systemic hold of neoliberalism explains why proposals for public sector alternatives have been so thin on the ground and also why those that do prevail against the odds should be constrained from meeting wider goals than commercial viability. The institutional capacity to deliver public sector alternatives has been severely undermined so that even corresponding proposals remain limited, let alone delivery in practice.

As will be shown, these observations are borne out in acute form by the financial crisis that began in 2008 and the policy responses to it. The imperative to rescue the financial system from itself begs the question of "rescue it for what and how", and here there tends to be a yawning gap in 
real outcomes, especially in public provision, reflecting the extent to which policy has been geared towards supporting the private sector in general and finance in particular. This leads us to suggest that the building of public sector alternatives, on which the vast majority of the poorest in developing countries will continue to depend for provision of many of their basic needs into the foreseeable future, will have to dovetail with the building of broader policy initiatives and institutional capacity to deliver them. It is not, then, simply a matter of different policies and of a different politics that informs them. The most immediate, but far from final, task is one of placing finance at the service of delivery rather than the other way about.

But this is much simpler to say than to target and realise in practice as, even within the context of the global crisis for which finance is primarily responsible, its needs have commanded the deepest and prior claims on both resources and policy making. Whereas, for example, the rhetoric of reining in the speculation of, and rewards to, the financial system was prominent once its crisis broke, there has been an astonishing return to business as usual in the widest sense. As the Centre for Research on Socio-Cultural Change finds, those UK bodies reporting on the financial system, and how better to regulate it, drew upon a membership of "662 years of work experience and $75 \%$ of those years were spent in City [the London financial centre] occupations or servicing City needs" (CRESC 2009, 5). Further, "90\% of its witnesses came from finance or consultancy with revenue links to finance". Indeed, "Membership contained no non-financial businesses and their trade associations, no trade unions despite the unionisation of retail finance workers, no NGOs to represent consumers or press social justice agendas, no mainstream economists or heterodox intellectuals, very few politicians or civil servants" (CRESC 2009, 23). Significantly, even as witnesses, the representation of the public sector was notable for its absence. ${ }^{2}$

What is both striking and disturbing in these respects is the extent to which different constituencies other than those attached to finance have been marginalised or subordinated, almost as second nature, within both the institutions and processes of government. While CRESC (2009) has at least made this transparent in the case of reform and policy making in the UK, the dull weight of business as usual - or should that be unusual - is liable both to prevail and to go unnoticed in the developing world, with at most a necessary deference to more straitened circumstances as global recession hits. This is crucial both in understanding the fate of public sector alternatives in the past as well as in building their potential for the future. For the task is not only to build alternatives based on public sector provision but also to dig deeper into creating the conditions that allow them to emerge and to be sustained and to deliver the goods just as, putatively, neoliberalism has previously set about the same task on behalf of the private sector and finance with the current devastating results.

Our critical response begins in the third section of the chapter by addressing the nature of neoliberalism and how it has systematically, 
through financialization and otherwise, undermined the potential for public sector alternatives to emerge and prosper. The fourth section carries this further by reference to empirical developments around "public" service delivery and how the private sector has been promoted to be involved both directly and indirectly. The last section suggests that secure alternatives are only liable to be sustained by subordinating the role of finance and paying close attention to sector- and country-specific issues of provision within each of health care, water and electricity, for example, without neglect of generic issues such as equity, labour market conditions, and participatory forms of governance.

\section{FINANCIALIZATION}

Financialization is a relatively new term and has its roots primarily in heterodox economics and Marxist political economy (Fine 2007, Goldstein 2009), although it is liable to be increasingly adopted by orthodoxy. It has also been understood in a number of different, distinct, but connected and overlapping ways. First, at the most casual level, it refers to the astonishing expansion and proliferation of financial markets over the past 30 years, during which the ratio of global financial assets to global gross domestic product (GDP) has risen three times, from 1.5 to 4.5 (Palma 2009). ${ }^{3}$ That this might be indicative of dysfunction - why do you need three times as many financial services proportionately to oil the economy than previously? - has previously been much overlooked precisely because of the market success of financialization in terms of growth and rewards. As the variously infamous former US Treasury Secretary, chief economist at the World Bank, president of Harvard, and then Barack Obama's chief economic adviser Larry Summers has described the Efficient Market Hypothesis (as cited in Davidson 2008, 52; emphasis added):

The ultimate social functions are spreading risks, guiding investment of scarce capital, and processing and disseminating the information possessed by diverse traders...prices always reflect fundamental values...The logic of efficient markets is compelling.

The logic today is less compelling, not least to the bankers themselves who had previously deployed it to rationalise what is now being revealed to be a reality of inefficient, dysfunctional, and parasitical markets, with a rather different meaning materialising in the crisis to the notion of "spreading risks" than the intended reduction!

Second, financialization has been associated with the expansion of speculative assets at the expense of mobilising and allocating investment for real activity. This is most notable in the ex post recognition of the lax regulation of the financial sector and corresponding calls to put the speculative 
milch cow back in the barn and reduce the contamination between speculative and real investments. That real investment itself is speculative, being contingent upon uncertain future returns, and that competition in financing depends upon expanding systemic risk by potential contagion at a greater rate than individual risk, are not necessarily overlooked. But greater restraint is called for between barn and field.

Third, this is because financialization has been understood as both the expansion and the proliferation of financial instruments and services. These have given birth to a whole range of financial institutions and markets and corresponding acronyms that are simply bewildering, quite apart from futures markets for trading in commodities yet to be produced (for which carbon is the most fetishised) and, most infamously of all, sub-prime mortgages. The expansion of the latter and their bundling into derivatives that were traded on and on ultimately had the effect of triggering the crisis, and is indicative of the previous two aspects.

Fourth, at a systemic level, financialization has been located in terms of the dominance of finance over industry. Empirically, this is not a matter of finance telling industry what to do, as recent trends have witnessed corporations relying less rather than more upon financial institutions to fund their operations as they have been able to raise funds on their own account. Yet, especially in the US, even non-financial corporations have necessarily been caught up in the process of financialization as they have increasingly derived profitability from their financial as opposed to their productive activities. As the leading Financial Times journalist Martin Wolf has put it: ${ }^{4}$

The US itself looks almost like a giant hedge fund. The profits of financial companies jumped from below 5 per cent of total corporate profits, after tax, in 1982 to 41 per cent in 2007.

The corresponding implications for the level, pace and efficacy of productive activity have been highlighted by Rossman and Greenfield from a labour movement perspective:

What is new is the drive for profit through the elimination of productive capacity and employment. ... This reflects the way in which financialization has driven the management of non-financial companies to 'act more like financial market players'. $(2006,2)$

More generally, Stockhammer (2004) has been at the forefront in arguing that financialization has been at the expense of real investment.

Fifth, for some, not least as a defining characteristic of neoliberalism itself, financialization is perceived to be a strategy for redistributing income to a class of rentiers (Palma 2009; but see Lapavitsas 2009 for a contrary view). Certainly, the rewards to finance systemically and individually have been astonishing not least, once more, in the US, where real incomes for the 
vast majority of the population have stagnated over the last 30 years and any productivity gains have accrued to the top $1 \%$ of earners whose share in GDP had risen from less than 10\% to more than double this.

Sixth, though again with the US in the lead, consumption has been sustained by the extension of (consumer) credit, not least through the use of capital gains in housing as collateral. For some, this has been part and parcel of the leading role played by financialization in exploiting workers through provision of financial services at abnormally high levels of banking profits (dos Santos 2009, Lapavitsas 2009; but see Fine 2009d, 2010 for a critique). This is, however, a single element in the much broader system of financial arrangements at the global level that has witnessed huge balance of trade and payments deficits for the US, matched by a corresponding holding of US dollars as reserves by other countries (with dramatic increases for China in particular). This is a consequence of neoliberal policies to relax if not eliminate exchange controls, opening economies to vulnerability to capital movements and, thereby, requiring high levels of reserves as a safeguard. The paradox is that with all its deficits and minimal interest rates, the US dollar has not suffered a collapse despite failing to follow the neoliberal policy advice on such matters that it has sought to impose on other countries through the World Bank and IMF when similarly inflicted by deficits of lesser magnitudes. Previous crises elsewhere have been used to facilitate financialization by opening up financial markets to international, and especially US, participation.

However the term financialization is defined and used, it points to a complex amalgam of developments within global finance and in its interactions with, and consequences for, economic and social life more generally. For further, seventh, it is not merely the expansion and proliferation of (speculative) financial markets that are striking but also the penetration of such financing into a widening range of both economic and social reproduction: housing, pensions, health, and so on. This is, of course, of paramount significance for social and economic infrastructure and for the displacement of public by private sector provision, most notably in case of privatisation, which can lead to proliferation of financial assets and consultancies.

Thus, different approaches and contributions to financialization may offer different emphases, but there is equally a need to locate it within a theory of finance itself. For this, there are as many competing candidates as there are forms of finance, ranging from the now discredited efficient market hypothesis to analyses of systemic financial fragility (most closely associated with economist Hyman Minsky). It is not possible to appraise these here and offer a synthesis other than in the form of a number of conclusions - namely, that financialization:

- reduces overall levels and efficacy of real investment as financial instruments and activities expand at its expense even if excessive investment does take place in particular sectors at particular times (as with the dotcom bubble of a decade ago); 
- prioritises shareholder value, or financial worth, over other economic and social values;

- pushes policies towards conservatism and commercialisation in all respects;

- extends influence more broadly, both directly and indirectly, over economic and social policy;

- places more aspects of economic and social life at the risk of volatility from financial instability and, conversely, places the economy and social life at risk of crisis from triggers within particular markets (as with the food and energy crises that preceded the financial crisis).

Although financialization is a single word, it is attached to different forms and effects of finance. The discussion here has drawn much of its illustration from the US and the UK, and these have been in the forefront of financialization. Different countries have experienced financialization differently, and this is especially true of the developing world. It has, for example, been much less affected by international transmission mechanisms associated with toxic financial assets than through the slowdown in growth, corresponding export demand, and capital flows from direct foreign investment, aid, and migrant remittances. Nonetheless, financialization has been important in the developing world, with corresponding diversity of impacts on the way in which and the extent to which financial interests have been formed and have influenced policy. This has been especially important for social policy and provision of economic and social infrastructure generally conceived, not least through the influence of donor agencies. So, if financialization lies at the heart of neoliberalism, itself in crisis, what are future prospects?

\section{NEOLIBERALISM IS DEAD? LONG LIVE ...}

A striking feature of the current global crisis is the speed and depth with which the legitimacy of neoliberalism has been discredited. While the last recession on this scale, following the collapse of the post-World War II boom, also witnessed the loss of its ideological underpinnings - those of Keynesianism - it did so much more slowly. Keynesianism itself only emerged over a decade or more in response to the Great Depression of the 1930s, with a world war intervening before it was established as the new conventional wisdom before its own demise. The monetarist counter-revolution that replaced it and initiated the era of neoliberalism also took a decade to take hold, from the early 1970s. Today, though, the erstwhile pedlars of Tina ("there is no alternative" to neoliberalism) are understandably thin on the ground in the wake of the extraordinarily acute and systemic failure of what is the perfect market, or markets, those attached to finance.

To point to the crisis of neoliberalism does not in itself offer alternatives, and these also seem to be thin on the ground apart from the ad hoc appeals 
for stronger regulation of financial markets and particular Keynesian measures of demand management to temper the worst fallout from the credit crunch. We return to alternatives later but first consider the ideology of neoliberalism beyond the simple nostrum of leaving as much as possible to what are presumed to be the efficient workings of markets. For the ideology runs much deeper than posing the market and the individual against the state and officialdom, with the presumption that individuals endlessly pursue self-interest - legitimately when done through the market but also illegitimately through the state as in rent seeking and corruption. The role of the state, therefore, has to be minimised because it provides opportunities for purely self-seeking actors. This has the effect of disparaging the role that can be played by collective action and of denying the possibility of a public sector ethos.

Indeed, one of the consequences of neoliberal ideology is to have corruption defined as something that only takes place within the state. As the Asian Development Bank puts it, "The succinct definition [of corruption] utilised by the World Bank is 'the abuse of public office for private gain". 5 This conveniently excludes the extent to which corruption involves the private sector as one of its partners in crime. The corporate payer of bribes cannot, on this definition, be guilty of corruption - only the public sector receiver of the bribe can. And totally excluded are "corrupt" dealings entirely confined within the private sector for which the neoliberal expansion of the market allows for greater scope and by no means greater transparency.

Nor is neoliberal ideology a simple stance of being pro-market and antistate, for it is only able to be so on the basis of gathering mutually inconsistent stances together. This is most apparent in terms of economic analysis, for appeal is made to mainstream neoclassical economics for the static efficiency that accrues from perfectly working markets. This depends upon taking preferences, resources, and technologies as given, and relying upon the market to allocate those resources efficiently to most desirable uses in the absence of the distortions and the rent seeking that would derive from the interventions of the state (and its self-seeking officials). Irrespective of the extraordinarily demanding conditions for the market to work in this way, even on the theory's own terms (no externalities, increasing returns to scale, oligopolies, etc.), there is an alternative neoliberal rationale for reliance upon the market that is entirely different and incompatible with one based on static market efficiency. For the neo-Austrian strand of neoliberalism sees the market as the means by which imperfectly informed but innovative individuals can best bring about dynamic change, in major part relying upon the spontaneous emergence of the necessary institutions to support the market in this role (Denis 2004).

Such, in a nutshell, are the neoliberal arguments for laissez-faire, its stance on the economy. But the ideology does not rest there because it is generally recognised that the economy as market does not work in a vacuum and needs the state and other institutions, spontaneous or otherwise, 
as supports. Where these begin and end remains fuzzy, but the liberal veneer associated with the freedom of the individual within the market and the antipathy to the state is rapidly abandoned once it comes to the state's essential functions. We should recall that the first major experiment with neoliberalism was undertaken by the "Chicago Boys" in Chile in the mid-1970s. Not surprisingly then, although democracy is now seen as an element of good governance, neoliberalism has previously been associated with authoritarianism, conservatism and the limitations on freedoms once stepping outside the market. This is especially so in the case of labour markets and the antipathy to trade unions although, markedly over the more recent period for reasons that will emerge, there is a more ambiguous stance on social movements (and civil society). These have the potential to be politically conservative, to be market conforming and correcting, and to serve as an alternative to campaigning for more and more secure provision through the state.

Complementing the ideology of neoliberalism has been an equally prominent and familiar set of policies, especially for the developing world, associated with the Washington Consensus. These have included both privatisation and limits on government spending more generally, in deference to keeping a tight rein on budget deficits. But over the last decade or more, the Washington Consensus has given way to the post-Washington Consensus, which has, at least theoretically and rhetorically, distanced itself from neoliberalism. It presents itself as more state-friendly, as rejecting the notion that one (free-market) model fits all, and that both market and institutional imperfections offer a rationale in principle for a role for the state to make markets, and globalisation, work better through piecemeal intervention to that end (Fine et al., 2001, Jomo and Fine 2006, Fine 2009b). Yet, policy advice, and aid conditionalities in practice, despite the emergence of Poverty Reduction Strategy Papers and Millennium Development Goals, have often been criticised for departing very little from those associated with the original Washington Consensus. Indeed, the so-called augmented Washington Consensus may even be seen to have broadened the imposition of neoliberal policies, adding more conditionalities to those such as free trade, privatisation, deregulation, fiscal austerity, and so on. And, further compounding the potential confusion, there is the stance of John Williamson (2007), who is universally acknowledged as having originated the term Washington Consensus in the late 1980s. He explicitly distances it from neoliberalism as such and complains that the differences between the Washington Consensus and the post-Washington Consensus have been exaggerated by the supporters of the latter to garner higher profiles for themselves (see also Marangos 2007).

There is, then, considerable ambiguity if not confusion over exactly what constitutes neoliberalism in both ideological and policy terms. This is compounded once it is recognised that policies in practice are highly diverse across time, place, and area of application. This is so much so that some 
commentators have even questioned whether it is appropriate to talk about neoliberalism at all, not least because its ideological and policy content have been so diverse (Castree 2006 and Ferguson 2007, for example; but see also Hart [2002, 2008] for the need to take context into account in unravelling rather than rejecting neoliberalism [and globalisation] as macroinfluences).

Such concerns over the conceptual viability of "neoliberalism" are likely to have been reinforced by the response to the current crisis. For it broke while President George W. Bush was still in office in 2008, and policy took the form of immediate and extensive intervention by the US and other states to support the financial system, even to the point of taking financial institutions and so-called toxic assets into public ownership. Yet, such measures still carried the scent of neoliberalism despite its loss of legitimacy and that of the financial system in particular. It was not simply guilt by association in that the leading neoliberals, such as Bush, were doing the rescuing, but what they were rescuing and have continued to rescue, have been the very financial markets and institutions that prided themselves on their efficiency and efficacy - until they needed massive state support and received it more or less on demand.

This paradox is readily resolved once it is recognised that neoliberalism has never, in practice, been about withdrawal or minimising the state's economic role. On the contrary, neoliberalism has concerned state intervention to promote private capital. In this, though, it is not distinctive from the role of the state in the Keynesian period, where it is as well to remember that policy towards state-owned enterprises, for example, was often criticised for serving private capital at the expense of public provision. What does mark the neoliberal era of the past 40 years is the extent to which the interests of private capital in general have been identified with, if by no means reduced to, those of finance in particular.

Within the literature, this core feature of contemporary capitalism has been increasingly acknowledged by reference to the previously discussed notion of financialization (without necessarily recognising its connection to neoliberalism; Fine 2007). The term has been deployed with a number of different meanings but, as indicated, it is most appropriate to be allinclusive of these in order to incorporate not only the extraordinary expansion and proliferation of financial markets, derivatives, and instruments but also to acknowledge the extent to which these have penetrated into ever more areas of economic and social reproduction. At the forefront of these developments has been privatisation in all of its forms. The point is not to suggest that privatisation has simply been some sort of conspiracy on the part of finance to further its interests irrespective of those of others. Rather, as finance has increasingly come to the fore, so it has both promoted and benefited from privatisation with the additional effect of undermining the potential for, and nature of, alternatives.

In short, before addressing this in more detail, it is as well to recognise that neoliberalism is characterised by two fundamental aspects. First, it 


\section{Ben Fine and David Hall}

combines a complex, shifting, and generally inconsistent amalgam of ideology, scholarship, and policy in practice. Second, while this is generally true of representations of capitalism for other periods, the process of financialization is what has given the current period of neoliberalism its own peculiar character. In addition, neoliberalism can be adjudged to have gone through two roughly delineated phases, with the early 1990s as a boundary between them. For the first "shock" phase, the promotion of private capital in general and of finance in particular has taken precedence, but it neither originated with, nor was confined to, eastern Europe, where it did take extreme forms. The second phase, however, has had two aspects. One has been to respond to the conflicts and dysfunctions of the first phase but, more important, the second has been to sustain the process of financialization itself with, in a sense, the response to the current crisis expressing this in extreme form.

That neoliberalism has gone through two phases of the sort we have identified is well illustrated by the World Bank's shifting position on privatisation. In the first phase of shock therapy, both rhetoric and policy conformed to one another with the explicit aim of promoting as much privatisation as possible. The virtues of privatisation were lavishly praised, with any number of microeconomic and macroeconomic benefits promised to result. Interestingly, the mainstream scholarship of the time was considerably more cautious, emphasising that ownership as such does not matter as opposed to conditions of competition and regulation (Fine 1990). This was simply ignored and, not least from the privatisation think tank run from Margaret Thatcher's Cabinet Office, we were told to "just do it", irrespective of the objections and potential stumbling blocks for which abstract theory was demonised. Exactly the same unthinking and dogmatic approach was taken by the World Bank.

Over the past decade the World Bank's position has changed dramatically, although with a significant lag of five or more years on the shift from Washington Consensus to post-Washington Consensus. The delay allowed as much privatisation to be pushed through as possible after which the World Bank has gone through what it itself calls a "rethink", rejecting the idea that one model fits all. Perversely, it has even adopted the earlier academic wisdom that privatisation needs to be wedded to closer consideration of regulation and competition and has added consideration of other conditions such as sources of finance, customer access and capacity to pay for vital services.

In practice, however, this does not represent a "rethink" at all, other than as a means to push through more participation of the private sector and, ultimately, full privatisation itself (where possible, and otherwise drawing upon, for the private sector, risk-minimising public-private partnerships [PPPs]). For the privatisation programme of the first phase was already faltering by the mid-1990s, not entirely delivering on its promises in terms of levels of investment and performance. The easy and acceptable 
privatisations had already been pushed through, whether because of high levels of potential profitability or lack of effective popular resistance. The new strategy now involves the fuller use of the state's resources and capacities to incorporate the role of the private sector where previously it had been reluctant to engage. Significantly, the focus of World Bank strategy has been to shift aid for social and economic infrastructure from state to private or PPP provision, with a pecking order of telecommunications, energy, transport, and water as privatisation and private sector participation becomes harder to achieve. In other words, the rethink is concerned to push the state even further in favouring the private sector because of the latter's failure otherwise to provide. While, especially for water, state provision remains the predominant source for an overwhelming majority of the population, policy continues to be directed at supporting the private sector, or preparing the public sector for it as much as possible through commercialisation/corporatisation and otherwise holding back the extension of the public sector.

\section{NEOLIBERALISM IN ACTION}

By specifying the nature of neoliberalism, a stronger perspective can be taken on policy in terms of what has materialised in the past and what are the prospects for the future. First and foremost, it should be emphasised that much more is involved than simply reversing the ideologies and policies of neoliberalism as if it were a tap that can be turned on and off. For the thrust of our analysis, now made explicit, is to suggest that neoliberalism goes far beyond ideology and policy insofar as neoliberalism is systemically rooted in contemporary capitalism as a whole in the age of globalisation with financialization to the fore.

This has had profoundly negative implications for the extent to which we are able to draw upon recent experience for alternative models of public provision as ideal types since these have been crowded out and undermined. One useful way of recognising this is in terms of the momentum behind what has been called the "evaluatory trap" associated with privatisation and the commercialised forms of new public sector management more generally (Olson et al., 2001). Essentially, following upon privatisation, it is found that outcomes are not as promised for investment levels, quality and access of service, and so on. This then places demands upon the state to regulate, make amends for those excluded from creaming off of most profitable delivery, renegotiate and monitor contracts, etc..

Here, there are three important points. First, if costs and benefits of such outcomes had been known and fully assessed in advance, the privatisation would not have been seen to be so attractive and might not have been undertaken (as might now be anticipated in retrospect, on a grander scale, the extent to which finance has been deregulated). Second, the burdens upon the 
state to make privatisation a success are far from negligible. It is not simply a matter of handing everything over to the "free" market. This too is costly, not least in use of the state's resources and capabilities. Indeed, to regulate the private sector sufficiently and successfully may involve greater demands than the state running things itself as wider goals and objectives are always resisted or being undermined by the pursuit of private profit. Third, also required is a qualitative shift in the nature and capabilities of the state itself as it has become increasingly oriented towards regulating and promoting the private sector as opposed to serving public provision.

This can be seen in the development of policies in support of PPPs since 2008. The central rationale for PPPs is that they provide direct investment by the private sector as an alternative to public finance, thus reducing the need for public finance through increased government debt. The most fundamental problem with PPPs, or any form of privatisation, is that even in good times it is a more expensive way of financing capital than state borrowing (IMF 2004, OECD 2008). This extra cost is then carried by the state, which is the ultimate customer for public service PPPs such as hospitals or schools, or by users where the PPP is based on charges, such as toll roads or public transport, or some forms of water concessions. The state can manage this cost by providing guarantees of various kinds for the private loans, but at the expense of undermining the rationale: the "private" finance becomes in effect a public liability, which is why statisticians have begun insisting in the UK and elsewhere that PPPs should appear on government balance sheets (KPMG 2009).

The financial crisis has exacerbated this fundamental problem because the gap between interest rates paid by the private and public sector has widened, as companies have become unable to raise finance, thus increasing the relative costs of PPPs further. For existing PPPs needing to refinance their business, the problem has been even sharper. The response in a number of countries, including the UK, France, and India, has been to create special state financial agencies, which in effect borrow as the state and then lend it to private companies in PPPs. The International Finance Corporation (IFC) has created a similar "infrastructure crisis fund", aiming to use \$1.2-\$10 billion of public finance from the IFC itself and donors (Hall 2009). These measures have been generally derided as an implausible attempt to maintain the fiction that the finance is raised by the private entities themselves.

The state/public sector, national and international, now provides layers of guarantees for companies, and the burden of these guarantees is often effectively transferred to governments of developing countries. If a project is partly financed by the IFC, it gains a much better credit rating for the whole project because the IFC is in practice a "preferred creditor", which always gets repaid (Bayliss 2009). The Multilateral Investment Guarantee Agency (MIGA) - a World Bank division - is dedicated to providing insurance for political risk, and when the now discredited Enron claimed successfully in respect of a power station project in Indonesia, abandoned 
after the dictatorship of Suharto was overthrown, MIGA insisted that the Indonesian government reimburse the entire amount. Export credits provided by northern countries to companies selling to developing countries have a similar effect. The loans are structured so that the company is paid upfront, and then the government of the importing state is liable for repaying the debt (Greenhill and Pettifor 2002).

The donor countries also use some of their aid budgets to finance private sector activity in developing countries. This is done partly through funds which are dedicated to support private companies, such as Sweden's Swedfund International AB, France's Société de Promotion et de Participation pour la Coopération Économique (PROPARCO), and the Netherlands Development Finance Company (FMO), following the same principle as the IFC. The sectors covered include the full range of production industries, but the funds also support private activity in sectors such as telecoms, energy, health care, higher education, and waste management. They can be described as donor-state-owned private equity funds. At the end of 2007, these private equity funds of European donors stood at $€ 15.1$ billion, invested in 3385 projects. ${ }^{6}$ These funds could not invest in any project or service run directly by public authorities because they are only allowed to be invested in commercially viable operations involving a private company. As Swedfund states, "Our decisions regarding investments are based solely on business principles." 7 Returns to private investors become the criterion of success. The Commonwealth Development Corporation (CDC), the UK government's private investment fund, more than doubled the value of its assets between 2004 and 2008 to a total of $£ 2.7$ billion, of which $£ 1.4$ billion remained in cash in the UK, and increased its chief executive's salary to $£ 970000$ per year. This was regarded as a developmental success story: for the UK government, "financial performance is the principal indicator of CDC's development impact". ${ }^{8}$

International and national development banks have also adopted the role of "financier of last resort" for private ventures. When multinational corporation Bechtel insisted on leaving a water concession in Estonia, the European Bank for Reconstruction and Development (EBRD) stepped in to buy $25 \%$ of the equity, as a kind of "default private owner"; as PPPs became harder to finance in Europe in 2009, the European Investment Bank (EIB) agreed to finance over $50 \%$ of some schemes. The same role can be seen at the national level: in Brazil, for example, the national development bank, Banco Nacional de Desenvolvimento Econômico e Social (BNDES) was used to co-finance many of the privatisations of the 1990s as a partner to private companies. Following the election of the Lula government in 2002, BNDES was later used as a way of buying stakes in the same companies from multinationals as they left the projects.

Governments also provide implicit or explicit guarantees as purchasers, underpinning the returns on many forms of privatisation. For example, power purchase agreements with private electricity generators will pledge 
that state-owned distributors will buy output under "take-or-pay" deals for periods of 20-30 years; water treatment plants are built under similar contractual terms of long-term purchases at prices that guarantee returns; hospitals, schools, and sometimes roads may all rely on similar government spending guarantees.

Regulatory systems often have the effect of providing a virtual guarantee of a minimum rate of return, which may be used as an indirect guarantee for raising corporate finance. Utilities were able to issue corporate bonds even in 2009, unlike most other companies, and were able to issue index-linked bonds before the credit crisis, thanks to this implicit guarantee underlying regulated industries. French water multinational Suez has issued a local bond in Indonesia to refinance its water concession in Jakarta, paying off a Euro loan; the Spanish electricity multinationals Endesa (now owned by Enel) and Iberdrola both reduced their equity stakes in electricity companies in Latin America by issuing bonds and raising loans in local currency.

Long-term contractual rights to public spending are typical of PPP and PFI (private finance initiative) schemes, with much longer contractual periods (25-30 years or more) than conventional service contracts (e.g. for refuse collection it is three to five years). The effect is thus larger than with ordinary outsourcing - switching public spending from direct employment to purchasing from a private company. As a result, the public good becomes subordinate to the imperatives of designing a commercially viable contract. This may involve restructuring of the service itself (e.g. the previously national Ghanaian water service was split, to ring-fence the profitable area of the capital Accra with the rest of the country served by a separate, financially disadvantaged, state company [Fuest and Haffner 2007]). In Estonia and Italy the basis for assessing the viability of PPPs has been restricted to examination of the potential profitability of schemes, with no reference to public policy objectives or effective comparison with public sector alternatives (Friedrich and Reiljan 2007, Barretta and Ruggiero 2008).

The effect persists during the long life of PPP contracts. The contractual obligations render them immune from being cut on policy grounds, for example, so that any reductions in public spending fall disproportionately on services provided by staff employed directly by public authorities, because these are not part of a contract with a private company that would require compensation if the payments by the public authority were reduced. The contracts may even explicitly protect companies against the consequences of democracy. Contracts for private road schemes in the US, for example, include clauses giving companies "the right to object to and receive compensation for legislative, administrative, and judicial decisions". Contracts have become standardised with as much as $70 \%$ identical content, reflecting the cumulative expertise of corporate lawyers, whereas the public authorities with which they deal often have little or none (Dannin 2009). 
In this light, it is crucial to recognise how significant privatisation is for the functioning of the neoliberal state and vice versa, far beyond the selling off of state assets, the commercialisation of public services, and the deregulation of public and private provision. For every element of policy is potentially involved, along the dimensions connecting macro to micro as well as more broadly. Macroeconomic policy, for example, has been geared towards globalisation of financial markets which have long been recognised to press for excessive fiscal restraint, thereby reducing finance available for public investment.

One form of financial deregulation has been the relaxation of traditional restrictions on pension funds investments. These were typically restricted largely to investing in government debt, with extra incentives in the form of tax relief for the funds, which had multiple advantages in security and longterm assets to match their long-term liabilities, while offering the state a reliable source of demand for bonds and other government debt. Deregulation meant that funds were able to diversify into national and international equity investments, providing extra funds for private capital at the same time as governments were reducing their borrowing. One result has been that some of the largest pension funds have themselves become leading financiers of privatisation in its various forms: in Chile, for example, onethird of the water companies and a major electricity distribution company are now majority-owned by the Ontario Teachers Pension Plan (OTPP), a pension fund covering 284000 active and retired elementary and secondary school teachers in the province of Ontario (Canada), ${ }^{9}$ and in the UK, local government pension funds alone own as much as $3.5 \%$ of companies whose main business consists of contracted-out public service work, such as Serco and Capita.

The privatisation of public sector pension funds is another way in which pension contributions, made compulsory by the state, are diverted into private hands. Private funds can extract profits through administration fees, and invest solely on the basis of maximising returns - by contrast with governments, which may use such funds for development purposes. Argentina, for example, was persuaded by the IMF in 1994 to reorganise its pensions by creating private pension funds to receive and manage the compulsory pension contributions, from which the private funds extracted large administration fees, which rapidly made them unpopular. But this process too is contested: in 2008, the government of Argentina renationalised the funds. This not only reduced the cost to pensioners of administering the funds, it also restored to the government a significant flow of revenue, in the form of pension contributions, and ownership of a strategic slice of the economy: the pension funds owned $13 \%$ of all shares on the stock market. ${ }^{10}$ Not surprisingly, the rush to privatise pensions has now been caught short as stock markets have crashed. But the apparently more reasonable line of the international financial institutions of now shifting to a more mixed system of private, public, and safety nets is more a way of using the state's 
resources to restore whatever can be recovered for the private sector from the shambles in which it now finds itself (Fine 2009e).

The same neoliberal agenda is reflected in the mistrust of large state-run "sovereign wealth funds", especially those owned and run by governments of developing countries, which now have dominant shareholdings in some large US and European companies. These were feared to be using their power to pursue "political" objectives rather than simple profit maximisation. This fear was substantially modified during the crisis in 2008 when the funds were welcomed for investing in US banks, precisely because of the political imperative to rescue the current financial system, with the US dollar at its pinnacle as a reserve currency (despite the huge external and domestic deficits and minimal interest rates that would have both brought down any other currency as well as severe conditionalities in return for the support enjoyed by the US).

The interception of state revenues, or compulsory social insurance contributions, is a recurrent theme in the framework of privatisation. Public spending, or compulsory private spending, is legitimised as long as it is channelled through corporate entities. The US health care insurance companies, for example, lobbied the proposed health reforms by US President Barack Obama to insist that contributions required under the proposals be paid into a private scheme, not a public sector health insurance scheme. Public borrowing for infrastructure investment is seen as irresponsible if it takes the form of direct government borrowing and an increased deficit but legitimate and welcome when it is channelled through PPPs.

More recently, the crisis has sharply revealed the extent of US international and domestic indebtedness, the counterpart to which is a corresponding burden carried by developing countries, by no means confined to China (Rodrik 2006). Capital accounts have been liberalised so that accumulated stocks of dollar reserves have been required to guard against short-term capital flight. At the macro level, neoliberalism has also been associated with increasing inequality within economies, not least arising out of, or trickling down from, the excessive rewards accruing to those attached to finance with negative benefits in terms of the mobilisation and allocation of resources for investment.

Other areas of policy making, as with industrial and regional policy, health, education and welfare, research and development, and skills and training, have all been profoundly influenced by neoliberalism, quite apart from the pressure for "flexibility" in labour markets, signifying a race to the bottom in wages and working conditions. The priority assigned to private participation in delivery has squeezed public sector alternatives and the rationale for, and capacity to deliver, them. As already suggested, the logic and practice is to push for what the private sector can deliver with limited regard to broader social and economic objectives or the presumption that these should be picked up by other compensating policy measures. Whether this ever happens is a moot point as opposed to journeying 
further down the "evaluatory trap". There is also significant reliance upon devolution and decentralisation with the presumption of greater local and democratic participation, whereas this can often turn out to be the passing on of responsibility for delivery by an authoritarian central state without provision of support for necessary resources.

In short, neoliberalism is not just marked by policy and ideology favouring the private over the public sector, but this has itself been institutionalised within government capacity itself and the commercial pressures to which it responds. And this has been devastating for the potential for formulating and implementing alternative forms of public provision.

This institutionalisation takes a number of forms at global, regional, and national levels. At the global level, the key role is played by the World Bank, and especially its arm dedicated to financing the private sector, the IFC. While the World Bank has included privatisation conditionalities in many of its loans over the years, an increasingly high proportion of World Bank funds have been channelled through the IFC, effectively tying this flow of public money to the private sector. By the end of 2007, the IFC had committed over $\$ 10$ billion for this, double the level of just four years earlier (Bayliss 2009). A special advisory unit, the Public-Private Infrastructure Advisory Facility (PPIAF) has promoted PPPs globally since 1999. Both agencies actively spend money on propaganda activities promoting PPPs: for example, the IFC allocated \$500 million a year to investing in PPPs in India, including \$20 million for "advisory services and support staff". ${ }^{11}$

The regional development banks, especially the African Development Bank and the Inter-American Development Bank (IDB), have also actively promoted various forms of privatisation in their regions; the European Commission has promoted PPPs throughout Europe. The institutionalisation of corporate interests can be seen even in UN bodies: UNESCO receives financing from the leading water multinational, Suez, and the United Nations Economic Commission for Europe (UNECE) now plays a leading role in promoting privatisation and PPPs across the countries of eastern Europe and central Asia (Hall and Hoedeman 2006).

More generally, government and international policy making itself is subject to institutionalised corporate capture/influence through the extensive use of management consultants and business appointees. These consultancies are themselves made up of a small group of multinational firms - such as PriceWaterhouseCoopers, Deloitte, Ernst and Young - which act as a policy replication mechanism. Another form of this is the appointment of increasing numbers of businessmen and women to government policy positions, which would normally be held by career civil servants. The process can also be seen at an international level, most obviously in the collaboration between companies, donors and development banks over privatisations.

The institutionalisation of these relationships can be seen as a generalised, if tacit, form of collusion, bordering upon corruption. For these individual acts occur as part of a systematic network between political parties 


\section{Ben Fine and David Hall}

and institutions on the one hand, and corporate interests on the other, regularly agreeing which policies to adopt, which companies get which contracts, and at what price (Della Porta and Vannucci 1999). The process includes not only bribes but also legal donations and other networks of influence, constituting effective "state capture" (Hellman et al., 2003). The operation of conditionalities by the development banks can also be recognised as tantamount to corruption, whereby money - in the form of finance for a socially and politically valuable project - is offered in exchange for a national government transferring assets and/or contracts to the corporate interests in the sector, through privatisation or PPPs.

At the national level, in sectors which are privatised, neoliberal orthodoxy insists that regulators must be "independent" of government. Responsibility for public policy in these sectors is thus transferred from elected ministries to bureaucracies, which are not subject to direct political intervention. The UK service regulators, for example, are constitutionally "government departments without a minister", a neat summary of this combination of state power without democratic direction. ${ }^{12}$ Such regulators are then subject to a well-recognised process of "capture" by the private corporations in the sector. This independence does not prevent corporate interests from continuing to lobby politicians to overrule inconvenient regulatory decisions, as happened in Argentina, for example, in the period of privatised water services in Buenos Aires (Lobina and Hall 2003).

Another form in which the role of the private sector is secured is through the creation by governments of special units, usually within finance ministries, to promote and manage PPPs. These units are dominated by business interests:

In Egypt, for example, all PPP Unit members are from the private sector - this helps because the staff is already in a position to understand private stakeholders' concerns. Moreover, extensive training was undertaken with the help of in-house consultants and outside training. A key element is also to have a balanced staff composition, including legal advice, bankers, accountants, etc.. (IFC 2009b, 16)

A key function is the (re)education of civil servants:

A PPP Unit can help by providing a focal point for education and dissemination of knowledge, as well as driving the process. In India, for example, at the inception of the PPP Program, IDFC acted as a so-called 'secretariat of thoughts' to bridge the thinking between the private sector and public sector, change the mindset of government officials and their understanding of the value the private sector brings to the table, and to align incentives. This process, like any fundamental change, takes time. (IFC 2009b, 15) 
There are now attempts to combine these global and national institutions into a wider international pressure group for PPPs. An international conference on PPPs in May 2009, involving the World Bank, the Asian Development Bank, UNECE, and various Asian governments, was presented with a lucidly expressed argument that the political conditions exist for an alternative based on a stronger role for the state (Hamilton 2009):

Discontent, even outright hostility, among the general public against the capitalist system has gained ground during the crisis.... The "system" is mistrusted, and confidence in capitalism and its future is low...The crisis appears to have had its roots in the era of deregulation and is replaced by the growing role of the state in managing financial capitalism and exercising accountability previously absent in the system;...PPPs are equated with the now discredited privatisation and financial liberalisation.

This was not presented by a critic of PPPs, but by an official of UNECE, an extremely anxious supporter of this form of privatisation. His conclusion was that there was a need for "tools to bring back the banks and new institutions able to articulate a pro-PPP policy in the crisis (and those in the future)... ga global advocate to spread support and the message around the globe: an alliance of PPP units". Thus, the international financial institutions and national finance ministries - all public sector institutions sustained by public finance - would combine to act as a de facto international lobby group to protect PPPs and discourage a revival of direct state funding and provision of infrastructure. The objective is not, however, to cut or eliminate state expenditure. Hamilton (2009) also argued that the crisis brought opportunities for potential PPPs because of the economic, social, and environmental needs for public spending:

The potential demand for social infrastructure such as public lighting, hospitals, and schools, is amplified in volatile times when financial and economic crisis negatively affect low-income people's life. The social infrastructure can not only serve as a safety net but also generate economic flow-on effects with increased human resource investment... There are ongoing needs to restore and replace much of the existing physical infrastructures, to accommodate population growth and to deal with the threats of global warming in response to the call for sustainable development.

Similar rhetoric is present in other IFC documents. In a recent health care report, the IFC states that it aims to "help Africa address its health care challenges - including improving services to the poor"; that "the scale of the challenge has driven a reassessment of traditional approaches and a growing acceptance that the private sector should be a key part of the overall health strategy". And so the IFC is creating a $\$ 400$ million vehicle for 
equity investment, "[i]mproving the environment for private health care" and "educating health workers through PPPs" (IFC-World Bank 2009). The solution to the health needs of Africans turns out to be placing hundreds of millions of public dollars at the disposal of private companies.

As a health strategy, it was rejected by $\operatorname{Oxfam}(2009,1)$ in a comprehensive critique, which concluded that prioritising private sector delivery "is extremely unlikely to deliver health for poor people". Yet, the IFC "estimates that private sector entities have the potential to deliver between 45 and 70 percent of the needed increase in capacity" in the health sector, thereby recommending that governments needing the support of the private sector to fund the expected growth in health care demand must create an environment "supportive of significant private sector investment" (IFC 2009a, 15).

In addition, the role of private donor agencies in health, with the Gates Foundation at the fore, has become extremely important. They now provide levels of funding that are dominating official aid quantitatively and, to some extent, qualitatively. Not surprisingly, they are attuned towards nonstate, if not necessarily private, forms of provision, and their ethos is geared more towards private and clinically driven provision as opposed to public provision of primary and preventive health care and the broader conditions necessary for good health. As McCoy comments on Gates's funding of the World Bank:

More controversial is the award of two grants to the International Finance Corporation, whose mandate is to support private sector development. The reasons why the International Finance Corporation needs philanthropic funding are not clear, but this donation suggests that the Gates Foundation is keen to promote the growth of private health-care providers in low-income and middle-income countries, and is consistent with views that have been expressed by the foundation and the observation that private foundations generally view the public sector with scepticism and disinterest. (McCoy 2009, 1651)

It is also noteworthy that the World Bank's interventions into health have been at the expense of the World Health Organization, with "more than 80 per cent of WHO's funding...dependent on voluntary or so-called extra budgetary resources" (Koivusalo 2009, 159).

\section{CONCLUSION}

Where does this leave the promotion of alternative public sector provision into the future? Initially, we can draw two general lessons. First, there is a need to insulate public provision from financialization (the direct or indirect effects of turning provision into a financial asset however near or distant). Privatisation incorporates finance directly into services, with provision 
becoming subject to the vagaries of stakeholder value on the stock market; subcontracting does it indirectly as the firms involved require their own financial imperatives to be observed. In short, finance needs to be placed in a subordinate not a dominant position. This is easier said than done not least because, prior to the crisis, this was said to be true of the financial system in terms of its efficient mobilisation and allocation of funds for investment and its trading in risk. But financialization continues to impinge upon public provision in multifarious ways that can only be guarded against as opposed to being absolutely eliminated, at least for the foreseeable future.

Second, the vulnerability of public sector provision to erosion and distortion is a consequence of the absence of broader supportive institutions and policies in the wake of decades of neoliberalism. Alternative public sector provision and new, broader policy capacities, and corresponding means and sources of finance, must be built in tandem.

Beyond these two generalities, we would emphasise the need to address the specificity of particular types and circumstances of public sector provision in terms of the diversity of causes, content, and consequences to which they are subject, but without losing sight of the bigger picture. In particular, our own approach has been to posit the notion of public sector systems of provision (PSSOP). Specificity is incorporated by understanding each element of public provision as attached to an integral and distinctive system - the health system, the education system, and so on. Each PSSOP should be addressed by reference to the structures, agencies, processes, power, and conflicts that are exercised in material provision itself, taking full account of the whole chain of activity bringing together production, distribution (and access) and use, and the conditions under which these occur.

Thus, the PSSOP approach has the advantage of potentially incorporating each and every relevant element in the process of provision, investigating how they interact with one another, as well as situating them in relation to more general systemic functioning. This allows for an appropriate mix of the general and the specific and, policy-wise and strategically, signals where provision is obstructed, why, and how it might be remedied. This is in contrast to unduly focused approaches, those that emphasise mode of finance alone, for example, as has been the case for housing both before and after its current crisis (as opposed to emphasis on who is building what, how, and for whom, with what means of access). At the opposite extreme are unduly universal approaches such as those that appeal to market and/ or institutional imperfections, and which accordingly fail to recognise that water provision is very different from housing provision in and of itself as well as in different contexts.

The PSSOP approach has been addressed in Fine (2002) for the welfare state, in Bayliss and Fine (2008) for electricity and water, and in Fine (2009a, 2009e) for social policy. We are not so much concerned here to develop, let alone impose, the PSSOP approach more fully as such, for it is essential to see it as an approach that needs to be contextually driven rather 
than as a source of the ideal types or universal theory that characterises, and even mars, much of the current literature (leave things to the market, or correct market and institutional imperfections). Indeed, the purpose is rather to persuade of the need for something akin to the PSSOP approach irrespective of the method and theory with which it is deployed, which will, no doubt, continue to be controversial, alongside the nature, depth, and breadth of economic and social transformation essential for any significant change in provision to be secure. In other words, there is something different about water and housing, just as there is something different about South Africa and India.

Further, though, this does allow for the results of existing studies to be incorporated into the PSSOP approach to the extent that they do identify, however partially, the factors involved in provision and how they interact with one another. Of course, in practice, sectorally grounded approaches by electricity, health, and water appear to be adopted as if by second nature. But this has not necessarily been so of how they are analytically broached, where sectoral and contextual sensitivity often gives way to universal prescription driven by the neoliberal fashion of the moment, whether privatisation, user charges, or public-private partnerships. At the very least, the PSSOP approach offers a framework with which to address policy needs in light of provision deficiencies, broadly interpreted, as opposed to general models and blunt recipes drawing to the fullest extent upon the "market" - i.e. private capital and finance - in practice even when recognising its deficiencies in principle.

In addition, as highlighted in earlier accounts of the approach, not only is each PSSOP uniquely and integrally organised in provision, by country and sector, each will also be attached to its own meaning and significance for those engaged with (or excluded by) it. For example, whether public provision is seen as household risk management against vulnerability or collective provision towards developmental goals is both cause and consequence of material provision itself and, equally, subject to debate (or not insofar as different approaches exist in parallel with one another according to context). As also argued in the approach, the cultural (in the widest sense) system attached to each PSSOP is also integral with material provision and is generated along and around that provision itself. Without going into details, the culture and meaning of public provision thereby becomes subject to what has been termed the $8 \mathrm{Cs}$ - Constructed, Contextual, Chaotic, Construed, Contradictory, Contested, Collective, and Closed (Fine 2009c). This is important for developing and understanding the meanings attached to public provision, not least in prising them away from the negative stance attached to the neoliberal ideology of public provision.

One apparent weakness of the PSSOP approach, a consequence of its strength of examining provision comprehensively within sectors, is its distance, at least initially, from the synergies and interactions across sectors, as with the role of "horizontal" factors (as opposed to the "vertical") such as equity, labour conditions, and macroeconomic impacts. Arguably, 
however, these need to be addressed in their own right and in the context of particular sectors within which they are rooted. Indeed, as revealed in the sectoral and regional studies offered elsewhere in this book, the dialogue between generic and sectoral issues is vital in designing, promoting, and defending public sector alternatives.

\section{NOTES}

1. For the Bischoff and Darling (2009) and Wigley (2008) reports, respectively.

2. As is sarcastically remarked by CRESC of Wigley: "Of the 71 witnesses, some 49 came directly from finance and a further 15 came from consultancy activities which generally have revenue connections to finance. Quite remarkably, the public sector provided just one witness: presumably the knowledge and expertise of HM Treasury or Department of Business Enterprise Regulatory Reform were irrelevant to the story that Wigley told about the importance of defending this valuable activity" $(2009,25)$.

3. In absolute terms, global financial assets rose from $\$ 12$ to somewhere between \$196 and \$241 trillion from 1980 to 2007 (Blankenberg and Palma 2009, 531).

4. Financial Times. 2008. Why it is so hard to keep the financial sector caged. 6 February.

5. Asian Development Bank. www.adb.org/Documents/Policies/Anticorruption/ anticorrupt 300 .asp? $\mathrm{p}=$ policies.

6. www.edfi.be.

7. Swedfund International AB. www.swedfund.se/en/investments-andnew-markets/meet-the-entrepreneurs-who-have-already-invested/ health-care-in-ethiopia.

8. UK Parliament Public Accounts Committe 2009. Eighteenth Report - Investing for Development: The Department for International Development's oversight of CDC Group plc. 30 April 2009 HC 94 2008-09. www.publications. parliament.uk/pa/cm200809/cmselect/cmpubacc/94/9402.htm.

9. See OTPP (Ontario Teachers Pension Plan). www.docs.otpp.com/Infrastructure _2008_9B.pdf.

10. Economist. 2008. Harvesting pensions. 27 November; Financial Times. 2008. Argentina moves to nationalise pension funds. 21 November; Financial Times. 2009. Telecom Italia contests Argentina ruling. 13 April.

11. Financial Express. 2007. IFC to invest $\$ 5$ bn in India, to set up PPP advocacy unit, 15 March 2007. http://www.financialexpress.com/printer/news/194057/

12. Department for Environment, Food and Rural Affairs (Defra). 2008. Statutory Social and Environmental Guidance to the Water Services Regulation Authority (Ofwat). www.defra.gov.uk/environment/quality/water/.../ofwatguidance080922.pdf.

\section{REFERENCES}

Barretta, A. and Ruggiero, P. 2008. Ex-ante evaluation of PFIs within the Italian health-care sector: What is the basis for this PPP? Health Policy 88(1): 15-24.

Bayliss, K. 2009. Private sector participation in African infrastructure: Is it worth the risk? UNDP IPC-IG Working Paper Number 55, May. www.ipc-undp.org/ pub/IPCWorkingPaper55.pdf. 
Bayliss, K. and Fine, B. (Eds). 2008. Whither the privatisation experiment? Electricity and water sector reform in sub-Saharan Africa. Basingstoke: Palgrave Macmillan.

Bischoff, W. and Darling, A. 2009. UK international financial services - The future: A report from UK based financial services leaders to the government. London: HM Treasury.

Blankenberg, S. and Palma, G. 2009. Introduction: The global financial crisis. Cambridge Journal of Economics 33(4): 531-538.

Castree, N. 2006. Commentary. Environment and Planning A 38(1): 1-6.

CRESC. 2009. An alternative report on UK banking reform. ESRC Centre for Research on Socio-Cultural Change, University of Manchester. www.cresc. ac.uk/publications/documents/AlternativereportonbankingV2.pdf.

Dannin, E. 2009. Infrastructure privatisation contracts and their effect on governance. Penn State Legal Studies Research Paper No. 19. University Park, PA: Pennsylvania State University.

Davidson, P. 2008. Securitization, liquidity and market failure. Challenge 51(3): 43-56.

Della Porta, D. and Vannucci, A. 1999. Corrupt exchanges: Actors, resources, and mechanisms of political corruption. New York: Aldine Transaction.

Denis, A. 2004. Two rhetorical strategies of laissez-faire. Journal of Economic Methodology 11(3): 341-353.

dos Santos, P. 2009. On the content of banking in contemporary capitalism. Historical Materialism 17(2): 180-213.

Ferguson, J. 2007. Formalities of poverty: Thinking about social assistance in neoliberal South Africa. African Studies Review 50(2): 71-86.

Fine, B. 1990. Scaling the commanding heights of public sector economics. Cambridge Journal of Economics 14(2): 127-142.

- 2002. The world of consumption: The material and cultural revisited. London: Routledge.

- 2007. Financialization, poverty, and Marxist political economy, Paper presented at the Poverty and Capital Conference, University of Manchester, Manchester, United Kingdom, 2-4 July 2007. www.eprints.soas.ac.uk/5685/1/ brooks.pdf.

- 2008. The evolution of the anti-Washington Consensus debate: From "postWashington Consensus" to "after the Washington Consensus". Competition and Change 12(3): 227-244.

. 2009a. Social policy and the crisis of neoliberalism, Paper presented at the Conference on The Crisis of Neoliberalism in India: Challenges and Alternatives, Tata Institute of Social Sciences (TISS) Mumbai and International Development Economics Associates (IDEAs), Mumbai, India, 13-15 March. www. networkideas.org/ideasact/jan09/ia27_International_Conference.htm.

- 2009b. Development as zombieconomics in the age of neoliberalism. Third World Quarterly 30(5): 885-904.

. 2009c. Political economy for the rainbow nation: Dividing the spectrum? Paper presented at Making Sense of Borders: Identity, Citizenship and Power in South Africa, Annual Conference of the South African Sociological Association, Johannesburg, South Africa, June/July.

- 2009d. Financialization, the value of labour power, the degree of separation, and exploitation by banking, Paper presented at the SOAS Research Students, Summer Seminar Series, 30 April. www.eprints.soas.ac.uk/7480.

- 2009e. Financialization and social policy, Paper prepared for Conference on Social and Political Dimensions of the Global Crisis: Implications for Developing Countries, UNRISD, Geneva, Switzerland, 12-13 November. www. eprints.soas.ac.uk/7984. 
- (2010). Locating financialisation. Historical materialism 18(2): 97-116.

Fine, B., Lapavitsas, C. and Pincus, J. (Eds). 2001. Development policy in the twentyfirst century: Beyond the post-Washington Consensus. London: Routledge.

Friedrich, P. and Reiljan, J. 2007. An economic public sector comparator for public private partnership and public real estate management, Paper presented at the ASPE Conference, St Petersburg, Russia, 12 November.

Fuest, V. and Haffner, S.A. 2007. PPP - Policies, practices and problems in Ghana's urban water supply. Water Policy 9: 169-192.

Goldstein, J. 2009. Introduction: The political economy of financialization. Review of Radical Political Economics 41(4): 453-457.

Greenhill, R. and Petifor, A. 2002. Recommendations for the Export Credits Guarantee Department (ECGD) on debt and export credits. Cornerhouse Reports. www.thecornerhouse.org.uk/item.shtml? $\mathrm{x}=52009$.

Hall, D. 2009. A crisis for public-private partnerships (PPPs)? www.psiru.org/ reports/2009-01-crisis-2.doc.

Hall, D. and Hoedeman, O. 2006. Aquafed - Another pressure group for private water. PSIRU Special Report, March. www.psiru.org/reports/2006-03-WAquafed.doc.

Hamilton, G. 2009. Impact of the global financial crisis - What does it mean for PPPs in the short to medium term? Paper presented at the KDI/ADB/ADBI/ WBI Conference Knowledge Sharing on Infrastructure Public-Private Partnerships in Asia, Seoul, Korea, 19-21 May. www.pima.kdi.re.kr/eng/new/ event/090619/9-4.pdf.

Hart, G. 2002. Disabling globalization: Places of power in post-apartheid South Africa. Durban: University of Natal Press.

. 2008. The 2007 Antipode AAG Lecture - The provocations of neoliberalism: Contesting the nation and liberation after apartheid. Antipode 40(4): $678-705$.

Hellman, J., Jones, G. and Kaufmann, D. 2003. Seize the state, seize the day: State capture and influence in transition economies. Journal of Comparative Economics 31(4): 751-773.

IFC (International Finance Corporation). 2009a. The business of health in Africa. www.ifc.org/ifcext/healthinafrica.nsf/Content/FullReport.

- 2009b. Public Private Partnerships Seminar April 2009: PPP fundamentals through roads sector experiences - Overview, assessment and recommendations for improvement. www.ifc.org/ifcext/psa.nsf/AttachmentsByTitle/PPPseminar_ Report042009/\$FILE/PPP+Seminar+Report_April+2009.pdf.

IFC-World Bank. 2009. Health in Africa initiative 2009. www.ifc.org/ifcext/fias. nsf/AttachmentsByTitle/DonnorMeeting2009HiA/\$FILE/HiAInitiative.pdf.

IMF (International Monetary Fund). 2004. Public-private partnerships. www.imf. org/external/np/fad/2004/pifp/eng/031204.pdf.

Jomo, K. and Fine, B. (Eds). 2006. The new development economics: After the Washington Consensus. London: Zed Press.

Koivusalo, M. 2009. The shaping of global health policy. In Panitch, L. and Leys, C. (Eds), Morbid symptoms: Health under capitalism 145-167. London: Merlin Press.

KPMG. 2009. Evidence to House of Lords Select Committee on Economic Affairs, October 13. KPMG.

Lapavitsas, C. 2009. Financialised capitalism: Crisis and financial expropriation. Historical Materialism 17(2): 114-148.

Lobina, E. and Hall, D. 2003. Problems with private water concessions: A review of experience, PSIRU. www.psiru.org/reports/2003-06-W-over.doc.

Marangos, J. 2007. Was shock therapy consistent with the Washington Consensus? Comparative Economic Studies 49(1): 32-58. 


\section{Ben Fine and David Hall}

McCoy, D. 2009. The Bill and Melinda Gates Foundation's grant-making programme for global health. Lancet 373(9675): 1645-1653.

OECD (Organisation for Economic Co-operation and Development). 2008. Public-private partnerships: In pursuit of risk sharing and value for money. www. oecd.org/document/27/0,3343,en_2649_34141_40757595_1_1_1_1,00.html.

Olson, O., Humphrey, C. and Guthrie, J. 2001. Caught in an evaluatory trap: A dilemma for public services under NPFM. European Accounting Review 10(3): $505-522$.

Oxfam. 2009. Blind optimism: Challenging the myths about private health. www. oxfam.org.uk/resources/policy/health/bp125_blind_optimism.html.

Palma, G. 2009. The revenge of the market on the rentiers: Why neoliberal reports of the end of history turned out to be premature. Cambridge Journal of Economics 33(4): 829-869.

Rodrik, D. 2006. The social cost of foreign exchange reserves. International Economic Journal 20(3): 253-266.

Rossman, P. and Greenfield, G. 2006. Financialization: New routes to profit, new challenges for trade unions. Labour Education, Quarterly Review of the ILO Bureau for Workers' Activities 142. www.iufdocuments.org/www/documents/ Financialization-e.pdf.

Stockhammer, E. 2004. Financialization and the slowdown of accumulation. Cambridge Journal of Economics 28(5): 719-741.

Wigley, B. 2008. London: Winning in a changing world. London: Merrill Lynch Europe Limited.

Williamson, J. 2007. Shock therapy and the Washington Consensus: A comment. Comparative Economic Studies 49(1): 59-60. 